\title{
Preface: phytoplankton responses to human impacts at different scales
}

\author{
16th Workshop of the International Association of Phytoplankton Taxonomy \\ and Ecology (IAP)
}

\author{
Nico Salmaso • Luigi Naselli-Flores • \\ Leonardo Cerasino • Giovanna Flaim • \\ Monica Tolotti · Judit Padisák
}

Published online: 24 July 2012

(C) Springer Science+Business Media B.V. 2012

The 16th workshop of the International Association for Phytoplankton Taxonomy and Ecology (IAP) on phytoplankton responses to human impacts was held at the Agricultural Institute of S. Michele all'AdigeFondazione E. Mach from 21st to 28th August 2011. The stated IAP objectives are to get together pre-

Guest editors: N. Salmaso, L. Naselli-Flores, L. Cerasino, G. Flaim, M. Tolotti \& J. Padisák / Phytoplankton responses to human impacts at different scales: 16th workshop of the International Association of Phytoplankton Taxonomy and Ecology (IAP)

Electronic supplementary material The online version of this article (doi:10.1007/s10750-012-1252-4) contains supplementary material, which is available to authorized users.

N. Salmaso $(\bowtie) \cdot$ L. Cerasino - G. Flaim · M. Tolotti Department of Sustainable Agro-ecosystems and Bioresources, IASMA Research and Innovation Centre, Istituto Agrario di S. Michele all'Adige-Fondazione E. Mach, Via E. Mach 1, 38010 S. Michele all'Adige, Trento, Italy

e-mail: nico.salmaso@iasma.it

\section{Naselli-Flores}

Department of Environmental Biology and Biodiversity, University of Palermo, Via Archirafi, 38, 90123 Palermo, Italy

\section{J. Padisák}

Department of Limnology, University of Pannonia, Egyetem utca 10, Veszprém 8200, Hungary eminent as well as young scientists and students working on various aspects of phytoplankton taxonomy and ecology to discuss topics of current interest, to jointly examine water samples under the microscope and practice species identification under the guidance of leading experts, and to encourage young scientists to engage in taxonomy research-a field where expertise is vanishing.

No doubts that these objectives were achieved in the current workshop with 91 participants from 23 countries (Argentina, Australia, Austria, Brazil, Bulgaria, Canada, China, Croatia, Czech Republic, Denmark, France, Germany, Greece, Hungary, Israel, Italy, New Zealand, Spain, Sweden, Switzerland, Turkey, UK, Uruguay) attending the workshop, more or less equally divided between professional scientists and students. Grants were provided to encourage the participation of students. The hostel of the institute where the meeting was held provided a spectacular site located in the Adige Valley and surrounded by the Alps. The microscopy sessions in the afternoons were guided by established taxonomists and attended by keen-tolearn young scientists who jointly examined fresh and preserved samples brought by the participants.

The IAP was established in 1979, and since then held 16 workshops at different locations (Kristiansen, 1997). Since 1991, each workshop had a well-defined ecological theme, and taxonomic topics. Proceedings of all these workshops have been published as peerreviewed articles. Since the early 1990s these appeared in dedicated volumes of Hydrobiologia: 
1991: Baja, Hungary (Padisák et al., 1993)

1993: Mont Rigi, Belgium (Descy et al., 1994)

1996: Granada, Spain (Álvarez-Cobelas et al., 1998)

1998: Shrewsbury, England (Reynolds et al., 2000)

1999: Delta Marsh, Canada (Hamilton et al., 2000)

2002: Castelbuono, Italy (Naselli-Flores et al., 2003)

2005: Sapanca, Turkey (Albay et al., 2007)

2008: Golan Heights, Israel (Zohary et al., 2010)

As tradition in all IAP workshops, the 2011 meeting had two main foci, one was ecological, the other taxonomic. The ecological theme was Phytoplankton responses to human impacts at different scales, the taxonomic topics were: Chlorophyta, Dinophyta and selected taxa of Cyanobacteria.

Apart of the foreword, this volume presents a selection of 26 reviews and original research papers. It is structured around the ecological theme of the workshop with many papers addressing global impacts like climate change and local influences like land-use on phytoplankton structure. Other papers addressed the trait concepts and, analyzed wax and wane, ecological responses, or physiological properties of individual species in the context of the central topics. Taxonomic papers review present state of the systematics of coccoid green algae (Krienitz \& Bock, 2012), and provide an update to modern (2011) taxonomy of planktic heterocytous cyanobacteria (Komárek \& Mareš, 2012). Zapomělová et al. (2012) while discussing biogeographically interesting nostocalean species revised taxonomic positions of two formerly Anabaena species and Zhu et al. (2012) provided a taxonomic and phylogenetic evaluation of Limnothrix strains.

The IAP participants are grateful to the Autonomous Province of Trento, which contributed to fund the workshop. We are also grateful to the Agrarian Institute-E. Mach Foundation for providing the access to the facilities of the campus. We thank the Regione Trentino Alto Adige, the APT-Azienda Promozione Turistica (Trento), Uwitech (Mondsee, (A), and Corr-Tech (S. Giovanni Lupatoto, VR) for their support. We are grateful to the Leica Microsystems BM Medical (Padova) for loaning us the Leica microscopes for the duration of the meeting. The assistance of the directorate, the staff members and the students of the IASMA Research and Innovation
Centre was invaluable. Without their dedicated contribution the success of this meeting would not have been possible. Special thanks are due to Dr. Roberto Viola, the director of the IASMA Research and Innovation Centre, and to Dr. Ilaria Pertot, the coordinator of the Department of the Sustainable Agro-ecosystems and Bioresources Department. Dr. Domenico D'Alelio and Dr. Ukrike Obertegger provided great help and support in the general organisation of the meeting. Flavia Brescancin, Manuela Milan, Jayant Ranjan and Shiva Shams, members of the research centre, provided invaluable logistic help during the workshop. We greatly appreciated the assistance of the Administration of E. Mach Foundation, in particular Dr. Sabrina Tanzi, and of the director of the Hostel, Dr. Anna Maria Llupi. Special thanks are due to the CENTRAL EUROPE Programme (European Lakes Under Environmental Stressors, 2CE243P3) for help in financing the stay of some participants at the workshop.

In addition, we wish to thank the numerous referees who invested their time in preparing reviews for the manuscripts of this special issue and helping bring this volume to its present standard.

\section{References}

Albay, M., L. Naselli Flores \& J. Padisák (eds), 2007. Morphological plasticity of phytoplankton under different environmental constraints. Hydrobiologia 578: 157-161.

Álvarez-Cobelas, M., C. S. Reynolds, P. Sanchez-Castillo \& J. Kristiansen (eds), 1998. Phytoplankton and trophic gradients. Developments in hydrobiology. Hydrobiologia 129: 372 pp (Reprinted from Hydrobiologia ,Vol. 369/370).

Descy, J.-P., C. S. Reynolds \& J. Padisák (eds), 1994. Phytoplankton in turbid environments: rivers and shallow lakes. Developments in hydrobiology. Hydrobiologia 100: 214 pp (Reprinted from Hydrobiologia ,Vol. 289).

Hamilton, P. B., H. Kling \& M. Dokulil (eds), 2000. Cyanoprokaryotes and chlorophytes across trophic gradients. Hydrobiologia 438: 1-264.

Komárek, J. \& J. Mareš, 2012. An update to modern taxonomy (2011) of freshwater planktic heterocytous cyanobacteria. Hydrobiologia. doi:10.1007/s10750-012-1027-y.

Krienitz, L. \& C. Bock, 2012. Present state of the systematic of planktonic coccoid green algae in inland waters. Hydrobiologia. doi:10.1007/s10750-012-1079-z.

Kristiansen, J., 1997. From IAAP to IAP. Hydrobiologia 502: $1-2$.

Naselli-Flores, L., J. Padisák \& M. Dokulil (eds), 2003. Phytoplankton and the equilibrium concept: the ecology of steady state assemblages. Developments in hydrobiology. 
Hydrobiologia 172: 416 pp (Reprinted from Hydrobiologia, Vol. 502).

Padisák, J., C. Reynolds \& U. Sommer (eds), 1993. Intermediate disturbance hypothesis in phytoplankton ecology. Developments in hydrobiology. Hydrobiologia 81: 200 pp (Reprinted from Hydrobiologia, Vol. 249).

Reynolds, C. S., M. Dokulil \& J. Padisák (eds), 2000. The trophic spectrum revisited. Developments in hydrobiology. Hydrobiologia 150: 152 pp (Reprinted from Hydrobiologia, Vol. 424).

Zapomělová, E., O. Skácelová, P. Purmann, R. Kopp \& E. Janeček, 2012. Biogeographically interesting planktonic Nostocales (Cyanobacteria) in the Czech Republic and their polyphasic evaluation resulting in taxonomic revisions of Anabaena bergii Ostenfeld 1908 (Chrysosporum gen, nov.) and A. tenericaulis Nygaard 1949 (Dolichospermum tenericaule comb. nova). Hydrobiologia. doi: 10.1007/s10750-012-1034-z.

Zhu, M., G. Yu, X. Li, W. Tan \& R. Li, 2012. Taxonomic and phylogenetic evaluation of Limnothrix strains (Oscillatoriales, Cyanobacteria) by adding Limnothrix planctonica strains isolated from central China. Hydrobiologia. doi: 10.1007/s10750-012-1127-8.

Zohary, T., J. Padisák \& L. Naselli-Flores, 2010. Phytoplankton in the physical environment. Hydrobiologia 639: 239 pp. 